\title{
Fintech Indonesia User Legal Protection in Balance Borrowing Money Based on Information Technology
}

\author{
Sulistyandari ${ }^{1 *}$ \\ ${ }^{1}$ Faculty of Law, Jenderal Soedirman University, Purwokerto, Indonesia,
}

\begin{abstract}
The growth of FinTech companies in Indonesia is very rapid, currently, there are 142 FinTech Companies in Indonesia. The Financial Services Authority (OJK) continues to encourage the development of information technology-based financial service provider company (FinTech). OJK considers that the more number of FinTech companies, the better it would be. It is important to pay attention to legal protection for FinTech Users, because lending and borrowing services-based information technology has the potential to cause harm to FinTech users, besides being done online, the lender and recipient of the loan do not know each other, and there is no collateral in information technology-based lending and borrowing services. This paper discusses the legal protection of FinTech Users in information technology-based lending and borrowing services, and settlement of dispute in the event of a dispute between FinTech Companies and FinTech Indonesia Users. Legal protection for FinTech Users is provided in agreements made between FinTech Indonesia Companies and FinTech Users and law enforcement OJK Regulation No. 77/POJK.01/2016 The settlement of disputes by complaining to the FinTech Company, to the Financial Services Authority (OJK) or claiming through the General Court.
\end{abstract}

\section{Introduction}

Nowadays, Online business is not only e-commerce (online store), but also there is a new industry called financial technology or FinTech Indonesia. The existence of FinTech aims to make it easier for people to access financial products, to facilitate transactions and also to improve financial literacy. National Digital Research Center in Dublin, Ireland defines financial technology or FinTech as "innovation in financial services". Financial Technology comes from the word Financial which means finance; and Technology which means Technology, so that in layman it can be interpreted that FinTech is an innovation that involves the use of modern technology in the field of financial services.

There are many types of FinTech companies in Indonesia, among others, are engaged in payments such as DOKU, loans such as Temanusaha.com, retail investments such as IPOTFund, financial planning such as Ngaturduit com, and financial research such as Infovesta.com.

* Corresponding author : sulistyandari265@yahoo.co.id 
The growth of FinTech companies in Indonesia is very rapid. The Financial Services Authority (OJK) continues to encourage the development of technology-based financial service providers (FinTech). OJK considers that the more number of FinTech companies, the better it would be. Because it will help increase public financial inclusion, especially for remote areas who have not been touched by formal financial services. It is expected that FinTech will be able to improve the government and OJK programs on financial inclusion. The problem is the FinTech companies will usually withdraw funds from the public, therefore, its operational activities must also be regulated and supervised by the OJK. For this reason, OJK has issued OJK Regulation No. 77 /POJK.01/2016 About Information Technology-Based Lending and Borrowing Services. This OJK regulation stipulates that FinTech companies lending and borrowing services operating in Indonesia must be registered and follow the rules set by the OJK. They must comply with OJK regulations regarding operational permits, forms of institutions, business scope, financial reports, and capital. The purpose of this OJK Regulation is for the public to be able to meet cash needs quickly, easily, and efficiently, and to increase competitiveness and can be one solution to help MSME players to obtain funding access. In addition, it aims to provide legal protection to Users, the implementation of Information Technology-Based Lending and Borrowing Services.

Based on data from the Indonesian FinTech Association (AFI) there are 142 FinTech startups in Indonesia. but not all of them are registered and get operational permission from OJK. Thus, there is great potential to cause harm to FinTech Users, The problem in this research is how the legal protection for FinTech Indonesia Users in lending and borrowing money services, and how to settle it if there is a dispute between FinTech Companies and FinTech Indonesia Users.

\section{Methodology}

The approach method in this research is a normative juridical approach, namely the approach of using secondary data or library data as the main data. Secondary data used in the form of primary legal material, namely Law No. 21 of 2011 concerning the Financial Services Authority (OJK Law), OJK Regulation No. 77 /POJK.01/2016 About Information Technology-Based Lending and Borrowing Services, Contracts between FinTech Companies and FinTech Users, secondary legal materials in the form of literature and documents relating to problems in this study Data analysis method is qualitative normative, that is the data obtained will be interpreted based on legal norms and relevant legal theory in the form of sentence descriptions so that the answers to the problem can be obtained as a conclusion.

\section{Discussion}

\subsection{Legal Protection of FinTech Indonesia Users in Money Lending and Borrowing Services}

There are several concepts regarding legal protection. Legal protection is related to how the law provides justice, namely giving or regulating rights and obligations to legal subjects. In addition, it also relates to how the law provides justice to legal subjects whose rights are violated to defend their rights. Philipus M. Hadjon distinguishes legal protection into preventive and repressive legal protection. All means, including legislation, is preventive protection, which aims to prevent disputes. Handling of protection by the judiciary is repressive legal protection, which aims to resolve disputes. 
FinTech Indonesia users in lending and borrowing services are Lenders and Loan Recipients who use information technology-based lending and borrowing services domiciled or domiciled in the territory of Indonesia.

FinTech companies or information technology-based lending and borrowing service providers are Indonesian legal entities that provide, manage, and operate information technology-based lending and borrowing services.

According to Article 7 of the OJK Regulation No. 77 /POJK.01/2016 About Information Technology-Based Lending and Borrowing Services. FinTech companies or FinTech organizers must submit registration and license to OJK. To be registered and to get an operational permit from OJK, FinTech companies must fulfill the conditions that have been set in Article 8 and 11 of the OJK Regulation. If the requirements are not fulfilled within the time specified in the OJK Regulation, the FinTech Company will become an illegal FinTech Company.

According to Article 18 of the OJK Regulation No. 77 / POJK.01/2016, in carrying out lending and borrowing services based on information technology, there is an agreement between the FinTech Company and the Lender, and there is an Agreement between the Lender and the Borrower. The agreement is set forth in Electronic Documents. The agreement is the legal basis for the establishment of a legal relationship between FinTech Companies and FinTech Users (Lenders) and the legal basis for the establishment of a legal relationship between the Lender and the Borrower.

Based on the theory of contract law which is known as the principle of pacta sunt servanda, that agreement is a law for the parties who make it (Article 1338 paragraph 1 of the Civil Code). Based on the provisions of the Civil Code, those agreements give birth to legal engagements and give birth to legal relations in the form of rights and obligations for the parties who make them, what is the obligation of one party is the right of the other party. If one of the parties does not carry out the obligations born of the agreement, then the person concerned is considered to violate the rights of the other party, and the other party can defend that right by claiming their rights legally.

In an information technology-based loan and loan agreement between the lender and the loan recipient, the obligation of the loan recipient to repay the loan as agreed. In the implementation there is a possibility of default, paid responsibility is borne by the Lender, to reduce the agreed risk, namely insurance that will generate $70 \%$, if there is a default. To provide more legal protection to the Lender, in the future it is necessary to issue Payment Insurance in information technology-based money lending services.

According to Article 21 of the OJK Regulation No. 77 / POJK.01/2016, the FinTech Company with Users must mitigate risks. In order to mitigate risks FinTech companies must use escrow accounts and virtual accounts. FinTech companies must provide a virtual account for each lender. In the context of loan repayment, the Borrower makes payments through the Operator's escrow account to be forwarded to the Lender's virtual account.

OJK Regulation No. 77 / POJK.01/2016 also provides protection to Users of FinTech for lending and borrowing services based on information regulated in Article 29-40, as follows:

1) FinTech Organizers or Companies must apply the basic principles of User protection, namely: a. transparency; b. fair treatment; c. reliability; d. data confidentiality and security; and e. User dispute resolution is simple, fast, and affordable.

2) The Provider must provide and/or convey the latest information regarding Information Technology-Based Lending and Borrowing Services that are accurate, honest, clear and not misleading. The information contained in the document as evidence.

3) The Provider is obliged to convey information to the User regarding receipt, delay, or rejection of an application for Information Technology Based Lending and Borrowing Services by stating the reasons. 
4) The Organizer must use simple terms, phrases and/or sentences in Indonesian that are easy to read and understand by the User in each Electronic Document.

5) In the event that the Operator uses a standard agreement, the standard agreement must be prepared in accordance with the provisions of the legislation. Standard agreements used by the Operator are prohibited: a. state the transfer of responsibilities or obligations of the Operator to the User; and b. stating that the User is subject to new rules, additions, continuations and/or changes made unilaterally by the Operator in the period the User utilizes the service.

6) The Operator must be responsible for the loss of User arising from errors and/or negligence, the Directors, and/or employees of the Operator.

7) The Operator must have standard operating procedures in serving Users contained in Electronic Documents.

8) The Organizer is prohibited in any way, providing data and/or information about the User to third parties. The prohibition referred to is excluded in the case of a. Users give approval electronically; and/or b. required by statutory provisions.

9) The Operator must report electronically every month in the event that there is a User complaint accompanied by a follow-up to the resolution of the complaint referred to the OJK.

In addition, in Article 43 POJK No. 77 / POJK.01/2016 is regulated as a prohibition for FinTech Organizers as follows, a. conduct business activities other than Operator business activities as stipulated in this OJK regulation; b. acting as a Lender or Loan Receiver; c. provide guarantees in all its forms for the fulfillment of the obligations of other parties $\mathrm{d}$. issue bonds; e. provide recommendations to Users; f. publish fictitious and/or misleading information; g. offer services to Users and/or the public through private communication without the user's consent; and h. charge any fee to the User for filing a complaint.

All of the above provisions regarding the Agreement between FinTech Companies or Organizers and Users and OJK Regulation No. 77 /POJK.01/2016 concerning Information Technology-Based Lending and Borrowing Services including the provisions of the prohibition is a form of preventive legal protection for FinTech Users. because for FinTech Companies or Organizers who have received operational permits must comply with the above conditions, and compliance with the above provisions has been supervised by OJK, if violated will be subject to administrative sanctions by the OJK in the form of a. written warning; b. fines, namely the obligation to pay a certain amount of money; c. limitation of business activities; and D. license revocation. Repressive legal protection against financiers Users is a form of legal protection in the form of the Dispute Settlement Agency which aims to resolve the dispute between FinTech Users and Users.

\subsection{Settlement if There is a Dispute between FinTech Company and FinTech Indonesia Users.}

In the previous description, it is explained that the legal relationship between the Company or FinTech Provider and the User is based on the agreement made between the Operator and the Lender and the Agreement between the Lender and the Borrower. in addition, the legal relationship between the Operator and Users is regulated in OJK Regulation No. 77 /POJK.01/2016.

The relationship between the Operator and FinTech Users born of the agreement is a civil law relationship, so that if there is a breach of agreement, then it is a violation of civil rights, and therefore there are disputes / civil disputes. According to the doctrine, there are 2 (two) interpretations of civil disputes namely: 1) Narrow interpretation: that all civil disputes are included in the general judicial authority. 2) Broad interpretation: all disputes that are civil law, as well as disputes based on public law, It is included in the general court's authority to 
judge if in the case there is a violation of civil rights or violation of the subjective rights of individuals. Those who have the right to demand that their rights be fulfilled are those whose interests are violated by their civil rights. Therefore, if the User feels aggrieved by the FinTech Company in an information technology lending and borrowing service agreement based on information technology, then the person concerned can demand a settlement in the General Court.

Legal relations between Fintech Organizers and Users are also regulated in OJK Regulation No. 77 / POJK.01/2016 which is the implementing regulation of the OJK Law. The legal relationship between the Company or FinTech Providers and Users is a legal relationship between Financial Service Business Actors and Consumers.

If the Customer is harmed by the conduct of the Business Actor in carrying out financial service activities, then he can complain to the Company or to FinTech Organizer concerned, to the OJK, and OJK will resolve the problem based on the procedures of OJK Regulation No.1 / 2003 concerning Consumer Protection of Financial Services, and later the settlement of the dispute will be regulated in the OJK Circular concerning the implementation of information technology-based lending and borrowing services which are currently still in the draft stage of the OJK Circular.

Thus, from the description above, it can be concluded that if there is a dispute between FinTech Companies and FinTech Indonesia Users, the settlement is by filing a complaint to the FinTech Company or to OJK, or prosecuting the person in the General Court.

\section{Conclusion}

1. Legal Protection of FinTech Indonesia Users in Information Technology-Based Lending and Borrowing Services, they are, in the form of rights born from the Agreement between FinTech Companies and Users, and in the form of rights from OJK Regulation No. 77 / POJK.01/2016 concerning Information Technology-Based Lending and Borrowing Services. The Lender obtains a replacement right of $70 \%$ from the Insurance Party The loan recipient has failed to pay according to the agreement he made. FinTech users (Lenders and Recipients) obtain legal protection in the form of rights stipulated in Article 29 - 40 of the OJK Regulation No. 77 /POJK.01/2016 as preventive legal protection and in the form of rights obtained from the decision of the Dispute Settlement Agency which aims to resolve disputes between FinTech Companies and FinTech Users as repressive legal protection.

2. The Problem Solving in the event of a dispute between FinTech Companies and FinTech Indonesia Users, namely by filing a complaint with the FinTech Company, OJK or claiming the person concerned at the General Court, Contracts between FinTech Companies and FinTech Users, secondary legal materials in the form of literature and documents relating to problems in this study.

\section{Suggestion}

1. Formed Lender Guarantee Insurance in Information Technology Based Lending and Borrowing Services in the Invitations.

2. Immediately ratify the OJK Circular that regulates the settlement of disputes in the Information Technology-Based Lending and Borrowing Services. 


\section{References}

1. Anonym, Apa itu FinTech Indonesia, (www.finansialku.com, Accessed on Nopember 25, 2017)

2. J. Satrio, Hukum Perikatan Yang Lahir Dari Undang-Undang Bagian Pertama, (Citra Aditya Bakti, Bandung, 1993)

3. Sulistyandari, Hukum Perbankan: Perlindungan Hukum Terhadap Nasabah Penyimpan Melalaui Pengawasan Perbankan di Indonesia (Laros, Sidoarjo, 2012).

4. Philipus M. Hadjon, Perlindungan Hukum Bagi Rakyat di Indonesia, (Peradaban, Jakarta, 2007) 